\title{
Kajian Teologis Terhadap Markus 10:17-27
}

\author{
Mariduk Tambun \\ Sekolah Tinggi Teologi Excelsius Surabaya \\ mariduktambun@gmail.com
}

\section{Adi Putra}

Sekolah Tinggi Teologi Pelita Dunia, Tangerang

addiepoetra7@gmail.com

\begin{abstract}
This research is about theological studies on Mark 10: 17-27. The research was conducted to find out about the concept of the Kingdom of God contained in it. That is why researchers used a qualitative approach with literature review to examine this topic. As a conclusion from this research, several things are obtained, namely: it is found that the strong theological message in this passage is about the concept of the Kingdom of God. The concept of the Kingdom of God has become central to the mission and ministry of Jesus while on this earth. That is why the Canonical Gospels also make it a major theological issue in their gospel account. That is why in this passage, Jesus linked God's Kingdom with eternal life. Because the kingdom of God is about the salvation of sinful humans. The concept of the Kingdom of God in Mark 10: 17-27 is understood in three main topics, namely: The Kingdom of God means salvation, the Kingdom of God is not obtained through good deeds, and the kingdom of God concerns the suggestion that we love God more than humans.
\end{abstract}

Keywords: Kingdom of God, Mark, Parables of Jesus

\begin{abstract}
Abstrak: Penelitian ini tentang kajian teologis terhadap Markus 10:17-27. Penelitian dilakukan untuk mengetahui tentang konsep Kerajaan Allah yang termaktub di dalamnya. Itulah sebabnya, peneliti menggunakan pendekatan kualitatif dengan kajian pustaka untuk meneliti topik ini. Sebagai kesimpulan dari penelitian ini diperoleh beberapa hal yakni: dijumpai bahwa pesan teologis yang kuat dalam perikop ini adalah tentang konsep Kerajaan Allah. Konsep Kerajaan Allah memang menjadi sentral dalam misi dan pelayanan Yesus selama di bumi ini. Itulah sebabnya, Injil Kanonik pun menjadikannya sebagai isu teologis utama dalam catatan injil mereka. Itulah sebabnya dalam perikop ini, Yesus menghubungkan Kerajaan Allah dengan hidup kekal. Karena kerajaan Allah adalah menyangkut tentang keselamatan manusia yang berdosa. Konsep Kerajaan Allah dalam Markus 10:17-27 dipahami dalam tiga topik utama, yakni: Kerajaan Allah berarti tentang keselamatan, Kerajaan Allah diperoleh bukan melalui perbuatan baik, dan kerajaan Allah menyangkut tentang anjuran supaya kita lebih mengasihi Allah dari pada manusia.
\end{abstract}

Kata Kunci: Kerajaan Allah, Markus, Perumpamaan Yesus 


\section{Pendahuluan}

Perikop Markus 10:17-27 mendeskripsikan seseorang yang bertanya kepada

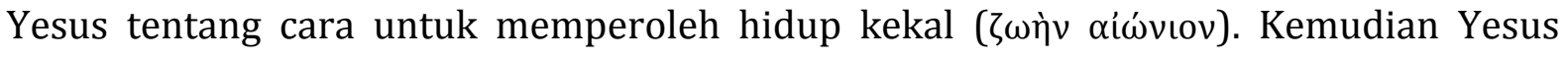
memberikan respons dengan menjelaskan tentang sepuluh perintah dalam kitab Taurat. Seolah-olah Yesus hendak mengonfirmasi, dengan melakukan semua perintah itu maka dapat memperoleh hidup kekal. Itulah sebabnya orang tersebut menanggapinya dengan berkata, "Guru, semuanya itu telah kuturuti sejak masa mudaku".

Hal yang menarik dalam narasi Markus selanjutnya ketika menjelaskan tentang tanggapan Yesus. Markus menjelaskan, "Tetapi Yesus memandang dia dan menaruh kasih kepadanya, lalu berkata kepadanya: "Hanya satu lagi kekuranganmu: pergilah, juallah apa yang kaumiliki dan berikanlah itu kepada orang-orang miskin, maka engkau akan beroleh harta di surga, kemudian datanglah ke mari dan ikutlah Aku." Ternyata jawaban Yesus ini menimbulkan persoalan serius bagi orang tersebut. Mengapa? Oleh karena dia memiliki harta yang banyak dan cenderung dia tidak rela melepaskannya demi "hidup kekal". Itulah sebabnya Yesus berkata dalam ayat 23, "Alangkah sukarnya orang-orang beruang masuk ke dalam Kerajaan Allah", dan dipertegas oleh Yesus dalam ayat 25, "Lebih mudah seekor unta melewati lobang jarum dari pada seorang kaya masuk ke dalam Kerajaan Allah".

Ungkapan Yesus dalam ayat 23 dan 25 inilah yang kemudian menjadi fokus makalah ini. Hal ini menjadi menarik diteliti karena karena pada awal kisah orang tersebut bertanya dan menghendaki "hidup kekal", namun mengapa pada akhirnya seolah-olah Yesus mengkaitkannya dengan Kerajaan Allah? Apa hubungan hidup kekal dengan kerajaan Allah? Apa maksud dari ungkapan kerajaan Allah dalam perikop ini? Dan bagaimana kemudian kita memahaminya secara teologis.

Pertanyaaan-pertanyaan di atas yang akan dijawab oleh makalah ini dengan menggunakan pendekatan kajian teologis. Dalam hal ini, tentunya yang digunakan adalah pendekatan teologis biblika. Itulah sebabnya dalam pembahasan makalah ini dijelaskan mulai dari pemahaman yang cenderung lebih luas, di mana melihat pengajaran injil kanonik terhadap konsep Kerajaan Allah. Kemudian dilanjutkan dengan membahas konteks Markus 10:17-27. Setelah itu, makalah ini mencoba menjelaskan motif perumpamaan harta terpendam dan mutiara yang berharga dalam Markus 10:17- 
27. Setelah membahas tiga topik di atas, kemudian dibahas tentang konsep kerajaan Allah dalam Markus 10:17-27.

\section{Metode Penelitian}

Pada penelitian ini, penulis atau peneliti menggunakan pendekatan atau metode kualitatif untuk memperoleh data yang valid guna membangun sebuah teori yang berkaitan dengan tema atau pokok penelitian. Metode kualitatif yang dimaksud adalah mengkaji dan mengelaborasi setiap sumber, informasi dan data-data yang diperoleh dari pustaka.

\section{Hasil dan Pembahasan}

\section{Kerajaan Allah dalam Injil Sinoptik}

Berbicara topik kerajaan Allah dalam Injil Sinoptik memang tidak dapat dipisahkan dan dilepaskan dari pribadi dan pelayanan Yesus. Tentunya, hal itu tidak dapat dilepaskan dari tendensi Injil Sinoptik (terutama Matius) yang hendak menegaskan Yesus sebagai penggenapan nubuat PL, khususnya yang berkaitan dengan pengharapan mesianik.

Itulah sebabnya, karena konsep Kerajaan Allah dalam Injil Sinoptik berkaitan dengan pribadi dan pelayanan Yesus maka dalam pembahasan ini difokuskan pada topik Pengajaran yang terpusat pada Kerajaan Allah. Di mana pengajaran Yesus juga tidak dapat dipisahkan dari Perumpamaan-Nya tentang Kerajaan Allah.

Urgensitas kerajaan Allah dalam pengajaran Yesus juga tampak melalui lokasi perumpamaan Yesus yang berbicara tentang kerajaan. Seperti dalam Matius 4:17 demikian pula dalam Markus 1:14-15 memperkenalkan pelayanan pengajaran Yesus dengan sebuah pernyataan yang tegas tentang kerajaan Allah. Menurut Thomas R. Schreiner mengatakan, "Yesus memberitakan kerajaan Allah sudah dekat dan penggenapan kabar baik bahwa Allah akan menebus umat-Nya”. ${ }^{1}$ Kemudian Adi Putra juga memberikan pendapat tentang ungkapan Yesus dalam Matius 4:17, "Bertobatlah, sebab Kerajaan Surga sudah dekat!2", dengan mengatakan:

\footnotetext{
1 Thomas R. Schreiner, New Testament Theology: Memuliakan Allah dalam Kristus, (Yogyakarta: Penerbit Andi, 2015), hlm. 20.

2 Ungkapan "sudah dekat" (engiken) dalam teks Matius 4:17 bertujuan untuk menggambarkan keekatan, mendekati, dan mendekatnya pemerintahan Tuhan yang direpresentasikan melalui kehadiran dan kedatangan Yesus di wilayah Kapernaum atau Galilea (Bdk. Walter Bauers, A Greek-English Lexicon of The
} 
Bahkan dapat dikatakan bahwa berita dekatnya kedatangan kerajaan Allah dilihat sebagai dasar bagi pertobatan. Oleh karena kerajaan Allah sudah atau akan segera datang, maka bangsa Yahudi diperintahkan untuk bertobat atau menyesal atas segala kejahatan dan perbuatan mereka yang tidak mempermuliakan Tuhan. Demikian pula bangsa-bangsa lain yang diperintahkan untuk meninggalkan segala kepercayaan lama mereka untuk kemudian beralih kepada Tuhan melalui percaya kepada Yesus. ${ }^{3}$

Berdasarkan apa yang dikemukakan oleh Schreiner dan Putra di atas memberikan indikasi yang cukup kuat bahwa konsep Kerajaan Allah dalam Injil dan dalam pengajaran Yesus berkaitan erat dengan keselamatan atau misi agung Allah untuk menyelamatkan manusia dari perbudakan dosa. Itulah sebabnya dalam pengajaran Yesus tentang kerajaan Allah seringkali dibarengi dengan ungkapan atau seruan pertobatan.

Pentingnya kerajaan Allah dalam pelayanan dan pengajaran Yesus juga ditunjukkan dalam Matius 4:23 $b d k$. 9:35; 24:14; Luk. 4:43. Di sana ditegaskan bahwa Yesus berkeliling di seluruh Galilea; Ia mengajar dalam rumah-rumah ibadat dan memberitakan Injil Kerajaan Allah serta melenyapkan segala penyakit dan kelemahan di antara bangsa itu. Schreiner mengatakan, "Pelayanan Yesus di Galilea terdiri dari pengajaran, kesembuhan, dan pemberitaan kabar baik tentang kerajaan. Sekali lagi hubungan antara ciptaan baru dan kerajaan muncul sebab kesembuhan setiap penyakit berarti tatanan lama sedang berlalu". ${ }^{4}$

Selain dalam pengajaran dan khotbah yang Yesus sampaikan mengandung pesan kerajaan Allah, demikian pula dengan pengajarannya dalam bentuk perumpamaan. Setiap kali Yesus menyampaikan perumpamaan, Dia selalu mengawalinya dengan frasa, “hal Kerajaan Allah... seumpama...". Frasa ini dengan jelas menunjukkan keterkaitan antara perumpamaan Yesus dengan Kerajaan Allah.

\begin{tabular}{|c|c|}
\hline Perumpamaan & Hal apa yang ditekankan \\
\hline $\begin{array}{l}\text { Perumpamaan tentang Empat Jenis } \\
\text { Tanah (Mat. 13:1-9, 18-13) }\end{array}$ & $\begin{array}{l}\text { Di dalam dan melalui pemberitaan Yesus, } \\
\text { kerajaan itu hanya sukses dalam hati } \\
\text { beberapa orang saja. Seluruh dunia }\end{array}$ \\
\hline
\end{tabular}

New Testament And Other Early Christian Literature (BDAG) Third Edition, (Chicago: The University of Chicago Press, 2000), hlm. 270. Diedit oleh: Frederick William Danker). Sedangkan Osborne mengatakan, "is near mengandung arti sudah dan belum... Yesus telah mengukuhkan peristiwa-peristiwa kerajaan, tetapi itu belum disempurnakan hingga akhir zaman" (Grant R. Osborne, Exegetical Commentary on The New Testament, (Grand Rapids, Michigan: Zondervan, 2010), hlm. 144).

3 Adi Putra, Misi Yesus Kepada Bangsa-bangsa Lain: Kajian Biblika terhadap Pelayanan Yesus di Galilea Berdasarkan Matius 4:12-17, (Jakarta: Penerbit Vieka Wahana Semesta, 2015), hlm.171-72

${ }^{4}$ Thomas R. Schreiner, New Testament Theology..., hlm. 20. 


\begin{tabular}{|ll|l|}
\hline & & $\begin{array}{l}\text { diubah secara dramatis, tetapi kerajaan } \\
\text { itu sedang bekerja. }\end{array}$ \\
\hline $\begin{array}{l}\text { Perumpamaan tentang Ilalang (Mat. } \\
\text { 13:24-30; 36-43) }\end{array}$ & $\begin{array}{l}\text { Meskipun kerajaan itu hadir dan aktif } \\
\text { dalam dunia, pergumulan dengan } \\
\text { kejahatan akan terus berlanjut. Kita tidak } \\
\text { dapat membedakan tanpa salah orang } \\
\text { yang sungguh-sungguh orang percaya } \\
\text { sejati. }\end{array}$ \\
\hline $\begin{array}{l}\text { Perumpamaan tentang Pukat (Mat. } \\
\text { 13:47-50) }\end{array}$ & $\begin{array}{l}\text { Kerajaan Allah menyapu seluruh dunia, } \\
\text { mengumpulkan semua ke dalam } \\
\text { pukatnya, baik yang baik maupun yang } \\
\text { jahat, tetapi hari penghukuman sedang } \\
\text { datang, hari ketika Kerajaan Allah akan } \\
\text { mencapai kesempurnaannya dan orang } \\
\text { jahat akan dihukum. }\end{array}$ \\
\hline Perumpamaan tentang Biji Sesawi & $\begin{array}{l}\text { Kerajaan Allah yang pada mulanya kecil, } \\
\text { namun semakin lama semakin besar dan } \\
\text { berkembang melalui pemberitaan Injil. }\end{array}$ \\
\hline
\end{tabular}

Berdasarkan penjelasan panjang lebar di atas, dapat dikatakan bahwa dalam pengajaran Yesus termasuk dalam khotbah perumpamaan yang seringkali disampaikan sangat kental dengan konsep kerajaan Allah. Bahkan setiap mukjizat yang juga dilakukan oleh-Nya memberikan penegasan tentang kehadiran kerajaan Allah.

\section{Konteks Markus 10:17-27}

Injil Markus secara dominan mendeskripsikan tentang Yesus sebagai Mesias dan Anak Allah. Di mana tema tersebut dinyatakan melalui pengajaran dan tindakan-Nya kepada orang banyak. Menurut I. Howard Marshall,

What takes place in Mark's story right from the beginning (Mrk. 1:2) is the fulfillment of Scripture and specifically of its propecies of future redemption through the coming of a messianic figure. Scripture explains the course of the Son of Man (Mrk. 9:12; 14:21, 27,49) and the rebelliusness and lack of spiritual comprehension of the people (Mrk. 4:10-12; 7:6; 11:17). ${ }^{5}$

Marshall hendak mengatakan bahwa apa yang terjadi dalam narasi yang dideskripsikan oleh Markus dari awal adalah penggenapan PL dan secara khusus dari para nabi perihal penebusan di masa depan melalui figur Mesias. Di sana dijelaskan pengajaran Anak Manusia dan pemberontakan serta kurangnya pemahaman rohani dari manusia (bdk. Mrk. 4:10-12; 7:6; 11:17). Dan apa yang dikerjakan oleh Yesus selama di

${ }^{5}$ I. Howard Marshal, A Concise New Testament Theology, (Nottingham, England: IVP Academic, 2008), hlm. 27. 
bumi berdasarkan penjelasan Markus adalah mengerjakan misi Kerajaan Allah. Marshall menambahkan, "The coming of the kingdom is closely linked with the Messiah; if he is here, the Kingdom is already being establised". ${ }^{6}$ Itulah sebabnya sejak awal kitab ini sudah memberikan indikasi tersebut. David Iman Santoso membenarkan pendapat di atas dengan mengatakan,

Maka kita mengetahui bahwa begitu Yesus memulai misi-Nya, Ia mengatakan bahwa Kerajaan Allah telah dekat, bahkan sudah ada di tengah-tengah umat manusia. Dan salah satu pekerjaan dalam misi-Nya ialah menyatakan keunggulan kuasa-Nya atas kuasa setan, yang pada akhirnya dinyatakan melalui kayu salib dan kebangkitan-Nya, yaitu kuasa yang mengalahkan maut. Maka kita dapat menyimpulkan bahwa pada waktu Yesus mengusir roh-roh jahat untuk menyatakan bahwa Kerajaan Allah ada di tengah-tengah manusia (Mat. 12:28). ${ }^{7}$

Dengan demikian, dapat dilihat bahwa dengan kehadiran dan mulainya pelayanan Yesus, maka Kerajaan Allah pun mulai menunjukkan kuasa-Nya di bumi. Dalam pemahaman di atas, kita coba mempersempit untuk melihat konteks Markus 10:17-27. Apabila melihat pasal 10 secara keseluruhan, maka pasal ini merupakan awal misi Yesus di Yudea setelah sekian lama di Galilea. Sebenarnya Yesus berjalan menuju Yerusalem untuk mengakhiri misi-Nya di bumi. Dan dalam perjalanan itu, Yesus singgah di Yudea sambil mengajar dan membuat mukjizat seperti yang dikisahkan dalam pasal 10. Pasal ini diawali dengan pengajaran Yesus tentang perceraian (10:1-12), kemudian dilanjutkan dengan Yesus memberkati anak-anak (10:13-16), Orang kaya sukar masuk kerajaan Allah (10:17-27), Upah mengikut Yesus (10:28-31), Pemberitahuan ketiga tentang penderitaan-Nya (10:32-34), Permintaan Yakobus dan Yohanes (10:35-45), dan ditutup dengan kisah Yesus menyembuhkan Bartimeus (10:46-52).

Pasal 10 sangat kuat menunjukkan tendensi kehadiran Kerajaan Allah melalui pribadi dan pelayanan Yesus. Oleh karena pasal ini berisi nuansa pengajaran tentang pengampunan dan bagaimana sikap lebih mengutamakan kasih kepada Tuhan dari pada yang lain sangat dikedepankan oleh penulis dalam pasal ini. Perhatikan tabel di bawah ini!

\begin{tabular}{|l|l|}
\hline Yesus tentang perceraian (10:1-12) & $\begin{array}{l}\text { Sebenarnya dalam konteks ini Yesus } \\
\text { tidak pernah menghendaki perceraian. } \\
\text { Yesus menghendaki setiap pasangan bisa } \\
\text { saling mengampuni. }\end{array}$ \\
\hline Yesus memberkati anak-anak (10:13-16) & Setiap anak-anak memperoleh panggilan \\
\hline
\end{tabular}

\footnotetext{
${ }^{6}$ Marshal, A Concise New Testament Theology, hlm. 27.

${ }^{7}$ David Iman Santoso, Theologi Markus: Intisari dan Aplikasinya, (Malang: SAAT, 2012), hlm. 25.
} 


\begin{tabular}{|l|l|}
\hline $\begin{array}{l}\text { Orang kaya sukar masuk kerajaan Allah } \\
(10: 17-27)\end{array}$ & $\begin{array}{l}\text { Untuk menjadi warga Kerajaan Allah } \\
\text { maka menjadi warga Kerajaan Allah, } \\
\text { Tuhan Yesus dibanding harta duniawi } \\
\text { yang dimiliki. }\end{array}$ \\
\hline Upah mengikut Yesus (10:28-31) & $\begin{array}{l}\text { Menjadi murid Yesus ada yang perlu } \\
\text { dikorbankan namun tentunya Tuhan juga } \\
\text { menyediakan upah }\end{array}$ \\
\hline $\begin{array}{l}\text { Pemberitahuan ketiga tentang } \\
\text { penderitaan-Nya (10:32-34) Yesus harus menderita, disalibkan dan } \\
\text { mati, supaya manusia berdosa dapat } \\
\text { ditarik masuk ke dalam kerajaan Allah }\end{array}$ \\
\hline $\begin{array}{l}\text { Permintaan Yakobus dan Yohanes } \\
\text { Yesus menyembuhkan Bartimeus (10:46- } \\
52)\end{array}$ & $\begin{array}{l}\text { Untuk menjadi murid sejati maka kita } \\
\text { harus melayani sesama }\end{array}$ \\
\hline $\begin{array}{l}\text { Kuasa Kerajaan Allah diekspresikan } \\
\text { Yesus untuk } \\
\text { manifestasinya di bumi }\end{array}$ \\
\hline
\end{tabular}

Dengan demikian, konteks perikop 10:17-27 adalah Kerajaan Allah sudah dekat dan sudah tiba melalui Yesus dan pelayanan-Nya. Sekarang bagaimana kita meresponsnya? Apakah kita mau dengan penuh kerelaan, pengorbanan untuk menjadi warga kerajaan Allah. Satu hal yang perlu digarisbawahi adalah bagian ini tidak mengajarkan bahwa untuk menjadi warga kerajaan Allah dapat diusahakan melalui perbuatan. Akan tetapi perikop ini memberikan kita pemahaman bahwa kerajaan Allahlah yang telah terlebih dahulu hadir di dunia dan memanggil semua manusia berdosa; sehingga manusia berdosa dapat melihat dan menemukannya. Namun perlu untuk digarisbawahi bahwa untuk menjadi warga kerajaan Allah kita perlu memberikan respons terhadap panggilan itu. Setiap manusia harus meninggalkan dosanya dan kehidupan lamanya untuk dapat masuk dan menjadi warga kerajaan Allah.

\section{Konsep Kerajaan Allah dalam Markus 10:17-27}

Apabila memperhatikan perikop ini dengan baik dan teliti, maka dapat dilihat bahwa minimal ada tiga (3) konsep teologi yang hendak diajarkan berkaitan tentang Kerajan Allah, yakni:

Kerajaan Allah adalah tentang Keselamatan. Apabila membaca perikop ini, maka orang muda tersebut datang dan menanyakan tentang bagaimana caranya dia memperoleh hidup kekal. Apabila berdiskusi tentang hidup kekal, maka topik ini tidak dapat dilepaskan dari topik keselamatan. Karena setelah manusia berdosa, maka manusia diganjar dengan kematian kekal. Bandingkan dengan ungkapan dalam Yohanes 
3:16, "Karena begitu besar kasih Allah akan dunia ini sehingga Dia telah mengaruniakan Anak-Nya yang Tunggal, supaya setiap orang yang percaya kepada-Nya tidak binasa, melain beroleh hidup yang kekal". William L. Lane mengatakan,

The question concerning the inheritance of eternal life, which has formal parallels in early Jewish material, places the discussion which follows in an eschatological perspective. The form of the question (What must I do to inherit eternal life?") implies a piety of achievement which stands in contrast to Jesus' teaching that a man must receive the Kingdom (or life) as a gift from God in his helplessness (Ch. 10: 15). In the light of verse 20, the man evidently thought that there were conditions to be fulfilled beyond those set forth in the Law. ${ }^{8}$

Intinya bagi Lane, pertanyaan tentang "hidup kekal" ini merupakan materi yang sudah muncul dalam tradisi Yahudi awal. Bentuk pertanyaan yang diajukan oleh seorang muda itu menyiratkan bahwa untuk memperoleh hidup kekal perbuatan yang baik (saleh) bertolak belakang dengan ajaran Yesus. Di mana Yesus mengajarkan bahwa menerima Kerajaan Allah sebagai sebuah pemberian dari Allah dalam ketidakberdayaan manusia termasuk orang muda yang kaya ini.

Sehingga berbicara hidup kekal berarti berbicara tentang keselamatan atau kerajaan Allah. Itulah sebabnya dari perikop ini, kita diberikan pemahaman bahwa kerajaan Allah erat hubungannya dengan keselamatan.

Kerajaan Allah tidak dapat diperoleh melalui perbuatan baik. Dalam perikop ini, dijelaskan dengan gamblang tentang sikap pemuda yang begitu percaya diri telah dan pasti akan dapat memperoleh hidup kekal karena telah melakukan semua hukum Taurat dengan sempurna. Menurut R. Alan Cole, "His impatient brushing-aside of the expected orthodox Jewish suggestion, that the way to life was by keeping the commandments, shows a spiritual perception far in advance of that displayed by the average scribe". ${ }^{9}$

Orang Yahudi pada zaman Yesus memang selalu menganggap diri layak untuk masuk dalam Kerajaan Allah dengan dua alasan: (1) Mereka adalah keturunan Abraham, dan (2) Mereka menjalankan hukum Taurat. Namun kemudian sejak kedatangan Yesus, Dia mulai memberikan pemahaman yang benar dan baru guna untuk membuka wawasan mereka. Bahkan Yesus pernah dengan sangat keras menegur

\footnotetext{
${ }^{8}$ William L. Lane, The New International Commentary on The New Testament: The Gospel of Mark, (William B. Eerdmans Publishing Company Grand Rapids, Michigan, 1974), hlm.365.

${ }^{9}$ R. Alan Cole, The Tyndale New Testament Commentaries: Mark, (Surabaya: Momentum, 2007), hlm.233.
} 
mereka, "Allah dapat menjadikan anak-anak bagi Abraham dari batu-batu ini" (Mat. 3:9).

Dalam perikop ini juga menjadi sebuah pelajaran penting bagi semua manusia bahwa keselamatan tidak dapat diperoleh hanya dengan melakukan hukum Taurat. Lane mengatakan, "The form of the question (What must I do to inherit eternal life?") implies a piety of achievement which stands in contrast to Jesus' teaching that a man must receive the Kingdom (or life) as a gift from God in his helplessness (Ch. 10: 15)".10 Singkatnya, perbuatan baik, perbuatan moral dan perbuatan beretika, tidak dapat menyelamatkan manusia. Yang benar adalah keselamatan kita akan memampukan kita melakukan perbuatan baik, perbuatan bermoral, dan beretika. Setiap perbuatan baik yang dilakukan atas dasar iman dalam Yesus Kristus adalah perbuatan yang benar dan menunjukkan bahwa kita adalah warga kerajaan Allah.

Kerajaan Allah adalah Kita harus lebih mengasihi Tuhan daripada yang lain. Dalam ayat 21-22 memberikan sebuah indikasi yang kuat bahwa pemuda itu lebih mengasihi hartanya daripada Yesus. Bahkan ayat 22 mengatakan, "Mendengar perkataan itu ia menjadi kecewa, lalu pergi dengan sedih, sebab banyak hartanya".

Ketika setiap orang mengasihi Tuhan lebih daripada apapun yang ada dalam dunia ini, maka pasti akan mengorbankan semuanya demi mengikut Tuhan. Bandingkan dengan Zakheus saat sebelum dan setelah mengenal Yesus. Sebelum Zakheus mengenal Yesus, dia begitu mengasihi hartanya. Bahkan dia akan menghalalkan segala macam cara untuk mendapatkan dan mengumpulkan harta bagi dirinya sendiri. Tetapi setelah mengenal dan berjumpa (bahkan menerima) Yesus, maka semua hartanya tidak lagi berarti karena sekarang Yesus lebih berarti baginya. Itulah sebabnya, dia membagibagikan semua hartanya karena kasihnya sudah diberikan kepada Yesus. Hal inilah yang sebenarnya diharapkan oleh Yesus dari anak muda itu. Yesus ingin supaya dia lebih mengutamakan kasih kepada Tuhan daripada kasih kepada harta dunianya.

\section{Motif Perumpamaan Harta yang Terpendam dan Mutiara yang Berharga dalam Markus 10:17-27}

Perumpamaan harta yang terpendam dan mutiara yang berharga yang dicatat dalam Matius 13: 44-46 memiliki konteks yang cukup jauh dengan perikop dalam Markus 10:17-27. Hal ini karena perumpamaan tersebut hanya dicatat dalam Matius -

\footnotetext{
${ }^{10}$ Lane, The New International Commentary on The New Testament..., hlm. 365.
} 
atau dua Injil Sinoptik yang lain tidak memasukkan ke dalam catatannya. Simon J. Kistemaker mengatakan, "Kedua perumpamaan ini hanya terdapat di dalam Injil Matius dan berbentuk pasangan. Tidak diketahui apakah Yesus mengajarkan kedua perumpamaan ini secara berurutan atau apakah Matius yang menyusun materinya secara topikal dan menempatkan kedua perumpamaan itu bersama-sama; tetapi kenyataannya keduanya ditulis secara bersama-sama".11 Sedangkan Leon Morris memberikan komentar tentang perumpamaan ini dengan mengatakan,

"Matius mencatat tiga perumpamaan singkat yang ketiga-tiganya diawali dengan "Hal Kerajaan Surga itu seumpama..". Kedua perumpamaan pertama menekankan kerajaan ini, dan yang ketiga menunjukkan finalitas pemisahan yang akan terjadi di akhir zaman. Ketiga perumpamaan ini hanya muncul dalam Injil Matius".12

Apabila memperhatikan pendapat Kistemaker dan Morris di atas, maka keduanya sepakat tidak memberikan alasan mengapa kedua perumpamaan ini hanya muncul dalam Injil Matius. Sehingga kita tidak bisa dan tidak mungkin membuat opini. Akan tetapi satu hal yang perlu digarisbawahi dari kedua perumpamaan ini adalah keduanya memiliki motif yang sama dengan perikop dalam Markus 10:17-27.

Perumpamaan harta yang terpendam dan mutiara yang berharga dapat digolongkan ke dalam jenis triadik. Hal ini disimpulkan berdasarkan munculnya tiga karakter utama dalam keduanya. Tiga karakter utama tersebut adalah harta yang terpendam/mutiara yang berharga, orang yang menemukan harta itu/pedagang, dan harta milik yang mereka jual.

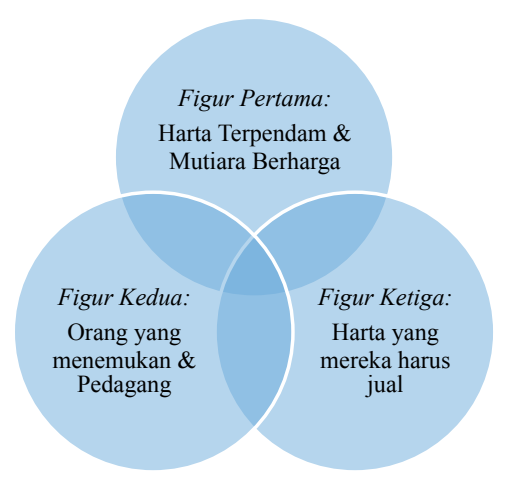

Apabila memperhatikan dengan baik narasi dalam perumpamaan tersebut, maka yang digambarkan oleh Figur Pertama adalah Kerajaan Allah. Karena dalam perkataan-Nya, Yesus secara gamblang dan jelas mengatakan bahwa, "Hal kerajaan surga seumpama dengan harta yang terpendam...." kemudian dilanjutkan,

"Hal Kerajaan Surga itu seumpama seorang pedagang yang menemukan mutiara berharga...”.

\footnotetext{
${ }^{11}$ Simon J. Kistemaker, Perumpamaan-perumpamaan Yesus, (Malang: SAAT, 2001), hlm. 55.

${ }^{12}$ Leon Morris, Tafsiran Pilihan Momentum: Injil Matius, (Surabaya: Momentum, 2016), hlm. 367.
} 
Kemudian figur yang kedua hendak menggambarkan manusia yang berdosa atau secara khusus dalam konteks ini adalah orang-orang Yahudi. Dan figur yang ketiga hendak menggambarkan harta duniawi yang harus dilepaskan supaya dapat memperoleh Kerajaan Surga tersebut.

Menurut Morris, harta di sini bisa berarti tempat untuk menyimpan hal berharga (2:11), tetapi juga menunjuk hal berharga itu sendiri. ${ }^{13}$ Apabila membaca narasinya dengan baik, maka memang harta itu sangatlah berharga, karena orang yang menemukannya rela menjual semua miliknya demi memperoleh harta yang terpendam itu. Kistemaker pun mengatakan,

Kemudian orang yang menemukan harta terpendam itu mungkin adalah orang bayaran atau seorang penyewa. Dia mungkin sedang mencangkul ladang14, menggali parit, atau menanam pohon. Apapun pekerjaannya, dia menyentuh sesuatu di dalam tanah dan tidak berbunyi, seperti sebuah batu. Dia menggalinya keluar dan menemukan sebuah harta yang terpendam... Harta tersebut dapat menjadi miliknya bila dia memiliki ladang itu... Dia memerlukan uang dan berkeinginan untuk menjual semua yang dia miliki. Orang mungkin akan terkejut menyaksikan keputusan yang tergesa-gesa; tetapi orang tersebut mengetahui apa yang sedang dia lakukan. Dia bisa membeli ladang dengan uang hasil penjualan semua miliknya tersebut untuk mendapatkan harta yang terpendam. ${ }^{15}$

Apabila mengamati apa yang dilakukan oleh orang yang menemukan harta tersebut tentunya akan membuat kita mulai memikirkan tentang sebuah pengorbanan. Apakah harta yang telah dimiiliki sebelumnya tidak berharga? Menurut saya berharga. Akan tetapi setelah menemukan harta yang terpendam itu maka semua yang dimiliki sebelumnya akan dia relakan.

Hal yang serupa dijumpai dalam perumpamaan mutiara ${ }^{16}$ yang berharga. Setelah pedagang itu menemukan mutiara yang berharga itu maka dia rela menjual seluruh harta yang dimilikinya. Menurut Kistemaker,

Pada zaman Yesus dan para Rasul, mutiara sangat diminati. Pedagang-pedagang harus pergi ke Laut Merah, Teluk Persia, dan juga India untuk mendapatkan mutiara. Mutiara yang rendah mutunya berasal dari Laut Merah; mutiara yang berasal dari Teluk Persia, pesisir Sri Lanka dan India lebih bagus mutunya. Seorang pedagang harus mengadakan perjalanan di dalam pencariannya untuk mendapatkan mutiara yang lebih besar dan lebih baik... Orang yang digambarkan

\footnotetext{
${ }^{13}$ Morris, Tafsiran Pilihan Momentum..., hlm. 367.

${ }^{14}$ Ladang bisa merujuk sepetak tanah untuk menanam atau memberi makan ternak, tetapi terkadang juga bisa merujuk kepada desa yang dibedakan dari kota.

${ }^{15}$ Kistemaker, Perumpamaan-perumpamaan Yesus, hlm. 57.

${ }^{16}$ Mutiara tampaknya tidak dikenal pada zaman PL, tetapi mutiara telah menjadi simbol status orang kaya pada abad pertama di zaman kekristenan. Bandingkan Matius 7:6; 1 Timotius 2:9; dan Wahyu 18:11,12.
} 
oleh Yesus, sedang mencari mutiara yang baik. Kita tidak mengetahui berapa jauh dia telah mengadakan perjalanan, tetapi pada hari yang ditentukan dia menemukan sebuah mutiara yang istimewa yang bernilai besar... Bagi dia, penemuan ini merupakan sebuah kesempatan di dalam kehidupannya. Dia tidak akan bahagia sampai mutiara tersebut menjadi miliknya. ${ }^{17}$

Oleh karena mutiaraitu sangat berharga, maka pedagang tersebut akan menjual segala harta milik yang dimiliki sebelumnya untuk membeli mutiara itu. Demikian pula yang terjadi pada orang yang menemukan harta yang terpendam. Menurut Morris, "Yesus tidak sedang berbicara tentang moralitas atau legalitas dari perbuatan orang ini. Yesus menegaskan bahwa adanya harta yang berharga sedemikian besar sehingga menjual segala sesuatu untuk mendapatkan harta itu layak dilakukan".18 Ditambahkan oleh Morris, "Yesus juga tidak sedang berkata manusia bisa membeli jalan ke surga; karena itu akan melawan semua ajaran-Nya. Penjualan seluruh harta milik merupakan cara untuk menyatakan..., menjadi warga kerajaan tak ternilai harganya". ${ }^{19}$ Atau ada harga yang harus dibayar. Hati kita harus terpaut kepada Allah bukan kepada harta duniawi. Kasih kita harus menjadi milik Allah bukan milik harta duniawi yang kita miliki.

Motif yang muncul dalam kedua perumpamaan ini juga terlihat jelas dalam perikop Markus 10:17-27, meskipun bertolak belakang. Oleh karena dalam Markus 10:17-27 juga memunculkan tiga figur utama, seperti yang tampak dalam perumpamaan harta yang terpendam dan mutiara yang berharga. Coba perhatikan bagan di bawah ini!

Hanya saja yang menjadi catatan kita adalah dalam perikop Markus 10: 17-27, pemuda tersebut tidak mau dan tidak rela menjual seluruh harta miliknya untuk kemudian menjadi pengikut Kristus atau masuk ke dalam kerajaan Allah.

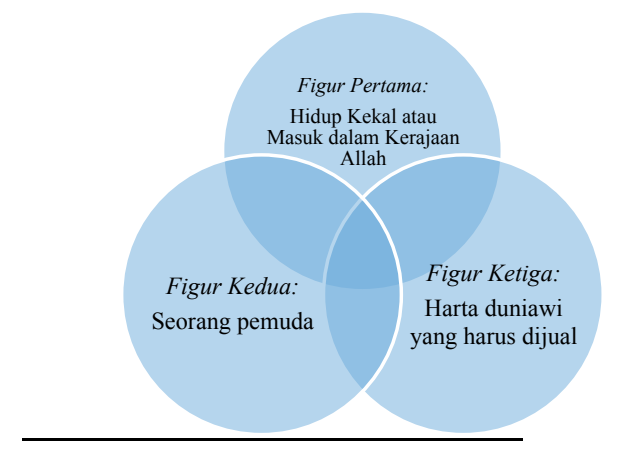

Sikap inilah yang dikatakn bertolak belakang dengan sikap dari pedagang dan orang yang menemukan harta itu. Oleh karena keduanya rela menjual semua hartanya demi memperoleh Kerajaan Allah (Surga) yang dalam perumpamaan itu digambarkan sebagai harta

\footnotetext{
${ }^{17}$ Kistemaker, Perumpamaan-perumpamaan Yesus, hlm. 58.

${ }^{18}$ Morris, Tafsiran Pilihan Momentum..., hlm. 368.

${ }^{19}$ Morris, Tafsiran Pilihan Momentum..., hlm. 368.
} 
yang terpendam dan mutiara yang berharga. Secara teologis, keduanya sangat identik, karena hendak menekankan sebuah prinsip penting yang harus dimiliki dan diketahui oleh semua orang Kristen yang merupakan warga kerajaan Allah. Supaya tidak mudah terpengaruh dan kasihnya tetap konsisten dan fokus kepada Allah.

\section{Kesimpulan}

1. Setelah melakukan Kajian Teologi terhadap perikop dalam Markus 10:17-27, maka di sana dijumpai bahwa pesan teologis yang kuat dalam perikop ini adalah tentang konsep Kerajaan Allah.

2. Konsep Kerajaan Allah memang menjadi sentral dalam misi dan pelayanan Yesus selama di bumi ini. Itulah sebabnya, Injil Kanonik pun menjadikannya sebagai isu teologis utama dalam catatan injil mereka. Itulah sebabnya dalam perikop ini, Yesus menghubungkan Kerajaan Allah dengan hidup kekal. Karena kerajaan Allah adalah menyangkut tentang keselamatan manusia yang berdosa.

3. Konsep Kerajaan Allah dalam Markus 10:17-27 dipahami dalam tiga topik utama, yakni: Kerajaan Allah berarti tentang keselamatan, Kerajaan Allah diperoleh bukan melalui perbuatan baik, dan kerajaan Allah menyangkut tentang anjuran supaya kita lebih mengasihi Allah dari pada manusia.

\section{Referensi}

Schreiner, Thomas R., New Testament Theology: Memuliakan Allah dalam Kristus, Yogyakarta: Penerbit Andi, 2015.

Bauers, Walter, A Greek-English Lexicon of The New Testament And Other Early Christian Literature (BDAG) Third Edition, Chicago: The University of Chicago Press, 2000. Diedit oleh: Frederick William Danker.

Osborne, Grant R., Exegetical Commentary on The New Testament, Grand Rapids, Michigan: Zondervan, 2010.

Putra, Adi, Misi Yesus Kepada Bangsa-bangsa Lain: Kajian Biblika terhadap Pelayanan Yesus di Galilea Berdasarkan Matius 4:12-17, Jakarta: Penerbit Vieka Wahana Semesta, 2015.

Marshal, I. Howard, A Concise New Testament Theology, Nottingham, England: IVP Academic, 2008.

Santoso, David Iman, Theologi Markus: Intisari dan Aplikasinya, Malang: SAAT, 2012. 
Mariduk Tambun, Adi Putra

Lane, William L., The New International Commentary on The New Testament: The Gospel of Mark, William B. Eerdmans Publishing Company Grand Rapids, Michigan, 1974. Kistemaker, Simon J., Perumpamaan-perumpamaan Yesus, Malang: SAAT, 2001.

Morris, Leon, Tafsiran Pilihan Momentum: Injil Matius, Surabaya: Momentum, 2016.

Cole, R. Alan, The Tyndale New Testament Commentaries: Mark, Surabaya: Momentum, 2007. 